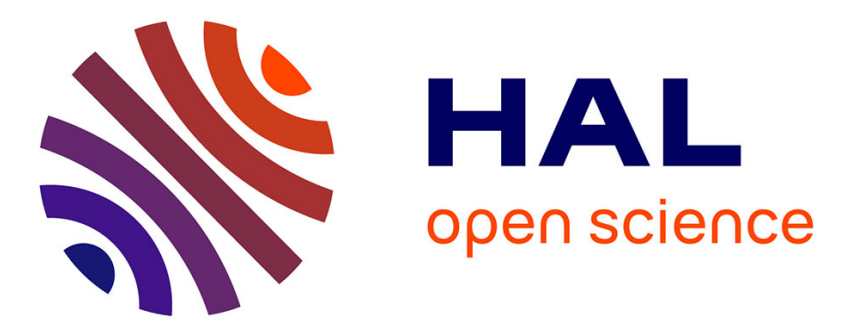

\title{
Cyclopentadienylmolybdenum(II) and -(III) complexes containing diene and allyl ligands. Part 4. Reactivity studies of the bisallyl complex CpMo(supine- $\eta$-C3H5)2 and the allyl-butadiene complex [CpMo(supine- $\eta$-C3H5)(supine- $\eta-\mathrm{C} 4 \mathrm{H} 6)][\mathrm{PF} 6]$.
} Rinaldo Poli, Li-Sheng Wang

\section{To cite this version:}

Rinaldo Poli, Li-Sheng Wang. Cyclopentadienylmolybdenum(II) and -(III) complexes containing diene and allyl ligands. Part 4. Reactivity studies of the bisallyl complex CpMo(supine- $\eta$-C3H5) 2 and the allyl-butadiene complex [CpMo(supine- $\eta$-C3H5)(supine- $\eta$-C4H6)] [PF6] .. Polyhedron, 1998, 17 (21), pp.3689-3700. 10.1016/S0277-5387(98)00164-8 . hal-03310668

\section{HAL Id: hal-03310668 \\ https://hal.science/hal-03310668}

Submitted on 6 Oct 2021

HAL is a multi-disciplinary open access archive for the deposit and dissemination of scientific research documents, whether they are published or not. The documents may come from teaching and research institutions in France or abroad, or from public or private research centers.
L'archive ouverte pluridisciplinaire HAL, est destinée au dépôt et à la diffusion de documents scientifiques de niveau recherche, publiés ou non, émanant des établissements d'enseignement et de recherche français ou étrangers, des laboratoires publics ou privés. 


\title{
Cyclopentadienylmolybdenum(II) and -(III) complexes containing diene and allyl ligands. Part 4. Reactivity studies of the bisallyl complex CpMo(supine- $\left.\eta-\mathrm{C}_{3} \mathrm{H}_{5}\right)_{2}$ and the allyl- butadiene complex [CpMo(supine- $\eta$ - $\left.\mathrm{C}_{3} \mathrm{H}_{5}\right)\left(\right.$ supine- $\left.\left.\eta-\mathrm{C}_{4} \mathrm{H}_{6}\right)\right]\left[\mathrm{PF}_{6}\right][1]$.
}

\author{
Rinaldo Poli, ${ }^{\text {a* }}$ and Li-Sheng Wang ${ }^{\mathrm{b}}$ \\ aLaboratoire de Synthèse et d'Electrosynthèse Organométalliques, Faculté des Sciences "Gabriel", \\ Université de Bourgogne, 6 Boulevard Gabriel, 21100 Dijon, France \\ ${ }^{\mathrm{b}}$ Department of Chemistry and Biochemistry, University of Maryland, College Park, Maryland 20742, \\ U.S.A.
}

(Received 26 February 1998; accepted 7 April 1998)

\begin{abstract}
Compound $\mathrm{CpMo}\left(\eta^{3}-\mathrm{C}_{3} \mathrm{H}_{5}\right)_{2}, 3$, has been synthesized from $\mathrm{CpMoCl}_{4}$ and four equivalents of allylmagnesium bromide. While the compound is stable in donor solvents at room temperature, warming in refluxing $\mathrm{MeCN}$ induces the formation of 1,5-hexadiene by a metal-mediated allyl-allyl coupling process. Treatment of 3 with $\mathrm{Bu}^{\mathrm{t} N C}$ at room temperature affords $\mathrm{CpMo}\left(\eta^{3}-\mathrm{C}_{3} \mathrm{H}_{5}\right)\left(\mathrm{Bu}^{\mathrm{t}} \mathrm{NC}\right)_{2}, \mathbf{4}$. A similar reduction with presumed allyl radical loss occurs for $\left[\mathrm{CpMo}\left(\eta^{3}-\mathrm{C}_{3} \mathrm{H}_{5}\right)\left(\eta^{4}-\mathrm{C}_{4} \mathrm{H}_{6}\right)\right]^{+},[1 \mathbf{c}]^{+}$, to afford $\left[\mathrm{CpMo}\left(\eta^{4}-\mathrm{C}_{4} \mathrm{H}_{6}\right)\left(\mathrm{Bu} \mathrm{NC}^{\mathrm{t}}\right)_{2}\right]^{+}$, 5. Treatment of $[\mathbf{1 c}]^{+}$with methyllithium affords two products, the major one (1c) corresponding to the oneelectron reduction pathway and the minor one $\left(\mathrm{CpMo}\left(\eta^{3}-\mathrm{C}_{3} \mathrm{H}_{5}\right)\left(\eta^{3}-\mathrm{C}_{3} \mathrm{H}_{4}-1-\mathrm{Et}\right), \mathbf{6}, \mathrm{ca} .4 \%\right)$ corresponding to nucleophilic addition. Protonation of the 1c:6 mixture affords a 2:1 mixture of cis and trans 2-pentene, in addition to propene. The room temperature $\mathrm{Cp}_{2} \mathrm{Fe}^{+} \mathrm{PF}_{6}{ }^{-}$oxidation of 3 in $\mathrm{MeCN}$ induces the immediate release of 1,5-hexadiene. The oxidation of $\mathbf{3}$ in $\mathrm{Bu}^{\mathrm{t} N C}$ gives complexes $\left[\mathrm{CpMo}\left(\mathrm{CNBu}^{\mathrm{t}}\right)_{3}\right.$ $\left.\left(\eta^{2}-\mathrm{CH}_{2}=\mathrm{CHCH}_{2} \mathrm{CH}_{2} \mathrm{CH}=\mathrm{CH}_{2}\right)\right]^{+} \mathrm{PF}_{6}{ }^{-}$(7, major) and $\left[\mathrm{CpMo}\left(\mathrm{CNBu}^{t}\right)_{4}\right]^{+} \mathrm{PF}_{6}{ }^{-}$(8, minor). Finally, the oxidation of 3 in the presence of butadiene, followed by treatment with $\mathrm{CD}_{3} \mathrm{CN}$, affords a mixture of $\left[\mathrm{CpMo}\left(\eta^{3}: \eta^{3}-\mathrm{C}_{3} \mathrm{H}_{4} \mathrm{CH}_{2} \mathrm{CH}_{2} \mathrm{C}_{3} \mathrm{H}_{4}\right)\left(\mathrm{CD}_{3} \mathrm{CN}\right)\right]^{+} \mathrm{PF}_{6}^{-}$, 9, and $\left[\mathrm{CpMo}\left(\eta^{4}-\mathrm{C}_{4} \mathrm{H}_{6}\right)\left(\mathrm{CD}_{3} \mathrm{CN}\right)_{2}\right]^{+} \mathrm{PF}_{6}^{-}$, 10. Thermal decomposition of this mixture affords butadiene and 1,5-cyclooctadiene.
\end{abstract}

\section{INTRODUCTION}

We have recently reported the preparation and properties of a molybdenum complex that contains a cyclopentadienyl, a butadiene, and an allyl ligand in four different isomeric forms and in two redox-related oxidation states, namely $\left[\mathrm{CpMo}\left(\eta-\mathrm{C}_{3} \mathrm{H}_{5}\right)\left(\eta-\mathrm{C}_{4} \mathrm{H}_{6}\right)\right] n+$

\footnotetext{
* Author to whom correspondence should be addressed Tel +33-03.80.39.68.81; fax +33-03.80.39.60.98; E-mail poli@u-bourgogne.fr.
}

$\left(n=0, \mathbf{1 a}-\mathbf{c} ; 1,[\mathbf{1} \mathbf{a}-\mathbf{d}]^{+}\right)$, see Scheme 1 [2]. In these isomers, the allyl ligand can adopt either a prone (a or d) or a supine (b or c) configuration, while the butadiene ligand adopts either a supine (s-cis) (a or b) or an $s$-trans (c or d) configuration. While the isomerization rates are slow in the Mo(II) manifold, allowing the isolation of each of the three isomers, they are rapid in the Mo(III) manifold, thus only the most stable isomer $[\mathbf{1 b}]^{+}$has been isolated in crystalline form as a $\mathrm{PF}_{6}{ }^{-}$salt.

We have subsequently reported on the reactivity of the coordinated ligands in the isomers $\mathbf{1 a}-\mathbf{c}$ and in the 


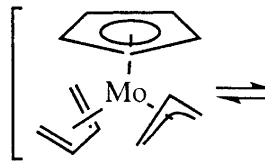

1a

$[1 \mathbf{a}]^{+}$

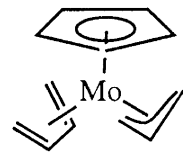

$1 b$

$[1 \mathbf{b}]^{+}$

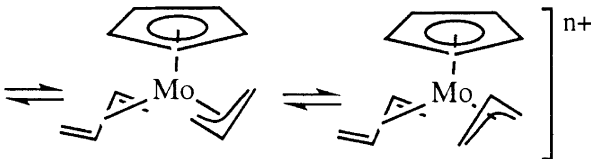

1c

$[1 \mathbf{c}]^{+}$ $(n=0)$

$[\mathbf{1 d}]^{+} \quad(\mathrm{n}=1)$

Scheme 1.

bis(diene) derivative $\left[\mathrm{CpMo}\left(\eta\right.\right.$-supine- $\left.\mathrm{C}_{4} \mathrm{H}_{6}\right)(\eta$-s-trans$\left.\left.\mathrm{C}_{4} \mathrm{H}_{6}\right)\right]^{+}, \mathbf{2}$, which is obtained by protonation of $\mathbf{1 a}$ in the presence of butadiene. While the s-cis-coordinated butadiene ligand is resistant to any kind of attack, the s-trans-coordinated butadiene can be attacked by either electrophilic or nucleophilic reagents depending on the electron richness of the system: electrophilic attack by protons has been observed for the neutral compound 1c [3], while nucleophilic attack occurs for the cationic complex 2 [4]. The allyl ligand has only been found to engage in electrophilic addition for any of the three isomers of $\mathbf{1}$ [3].

The reactivity of organic ligands coordinated to Mo(III) has not been the subject of extensive investigations. Compounds with either diene of allyl ligands on $\mathrm{Mo}(\mathrm{III})$ are known, e.g. $\mathrm{CpMoCl}\left(\eta-\mathrm{C}_{4} \mathrm{H}_{6}\right)$ [5] and $\mathrm{CpMo}\left(\eta-\mathrm{C}_{3} \mathrm{H}_{5}\right)_{2}[6,7]$, in addition to the complexes $[\mathbf{1 a}-\mathbf{d}]^{+}$recently reported by us. However, there is apparently no report on the reactivity of the coordinated $\pi$ ligands in these or other related compounds. In fact, compound $\mathrm{CpMo}\left(\eta-\mathrm{C}_{3} \mathrm{H}_{5}\right)_{2}, 3$, has been described as "depressively unreactive" [8]. A study of the reactivity of the allyl and diene ligands on Mo(III) is of interest for several reasons. First, it is interesting to examine the effect of the metal oxidation state on the reactivity of the ligands. Second, it is conceivable that a stoichiometric or electron-transfer-catalytic (ETC) $[9,10]$ oxidation of the more accessible Mo(II) precursors could allow the development of new stoichiometric or catalytic transformations that involve the coordinated ligands. In this report, we describe our exploratory investigations of the reactivity of the isoelectronic Mo(III) compounds $\mathbf{3}$ and [1/b $]^{+}$under a variety of conditions. We show that these complexes, under suitable conditions, are attacked by nucleophiles and electrophiles, undergo $\mathrm{Mo}-\mathrm{C}$ bond breaking and $\mathrm{C}-\mathrm{C}$ bond forming reactions, and engage in oxidative and reductive redox processes. A new and improved synthesis of compound $\mathbf{3}$ is also presented.

\section{RESULTS}

(a) New synthesis of $\mathrm{CpMo}\left(\mathrm{C}_{3} \mathrm{H}_{4}\right)_{2}$

The reaction of $\mathrm{CpMoCl}_{4}$ with 4 equivalents of allylmagnesium bromide involves chloride/allyl met- athesis and metal reduction, to provide a single-step synthesis of $\mathrm{CpMo}\left(\eta-\mathrm{C}_{3} \mathrm{H}_{5}\right)_{2}$ (see eq. (1). The unoptimized yield is moderate $(44 \%)$. Nevertheless, considering that $\mathrm{CpMoCl}_{4}$ can be easily prepared in a single, nearly quantitative step from commercially available $\left[\mathrm{CpMo}(\mathrm{CO})_{3}\right]_{2}[11]$, this procedure represents an improvement over the previously reported 3-step synthesis from $\mathrm{MoCl}_{4}(\mathrm{THF})_{2}$ via $\mathrm{Mo}\left(\eta^{3}-\mathrm{C}_{3} \mathrm{H}_{4}\right)_{4}$ and $\operatorname{MoCl}\left(\eta^{3}-\mathrm{C}_{3} \mathrm{H}_{4}\right)_{3} \quad[6, \quad 7]$. The precursor $\mathrm{MoCl}_{4}(\mathrm{THF})_{2}$ must also be prepared in two steps from commercially available $\mathrm{MoCl}_{5}$ [12] .

$$
\begin{array}{rl}
\mathrm{CpMoCl}_{4}+4 \mathrm{CH}_{2}=\mathrm{CHCH}_{2} & \mathrm{MgBr} \\
& \rightarrow \underset{3}{\mathrm{CpMo}\left(\eta-\mathrm{C}_{3} \mathrm{H}_{5}\right)_{2}}
\end{array}
$$

Compound 3 has previously been characterized by $\mathrm{X}$-ray crystallography, magnetic susceptibility, and cryoscopic molecular weight determination [6]. An EPR spectrum was not reported. We have recently observed that allyldiene complexes such as $[\mathbf{1}]^{+}$, isoelectronic with 3, exhibit sharp EPR absorptions with observable coupling to the diene and allyl protons [2]. Comparative studies have shown that the supine allyl ligand in $[\mathbf{1 b}]^{+}$gives measurable coupling to the syn $\mathrm{H}$ atoms but not to the anti $\mathrm{H}$ atoms or to the central $\mathrm{H}$ atom, whereas no coupling can be observed with either type of $\mathrm{H}$ atom for the prone allyl ligand in $[\mathbf{1 a}]^{+}[2,4]$. The spectrum of compound 3, shown in Fig. 1, consists of a pentet of pentets, indicating coupling with all the $\mathrm{H}$ atoms of the terminal allyl positions. This suggests that the configuration of $\mathbf{3}$ in solution is identical with that previously determined in the solid state, with both allyl ligands adopting a supine configuration. By comparison with our previous EPR studies, the stronger coupling of $6.6 \mathrm{G}$ is assigned to the syn $\mathrm{H}$ atoms and the weaker one of $3.3 \mathrm{G}$ to the anti $\mathrm{H}$ atoms.

\section{(b) Reaction of $\mathrm{CpMo}\left(\eta-\mathrm{C}_{3} \mathrm{H}_{5}\right)_{2}$ with nucleophiles}

Compound $\mathbf{3}$ is stable in donor solvents, including $\mathrm{MeCN}$ at room temperature. Warming a $\mathrm{MeCN}$ solution to the reflux temperature caused the complete decomposition of the complex and the formation of 1,5-hexadiene and propene in a ca: $2: 1$ ratio as the major products ( $>80 \%$ by ${ }^{1} \mathrm{H}$ NMR integration). 

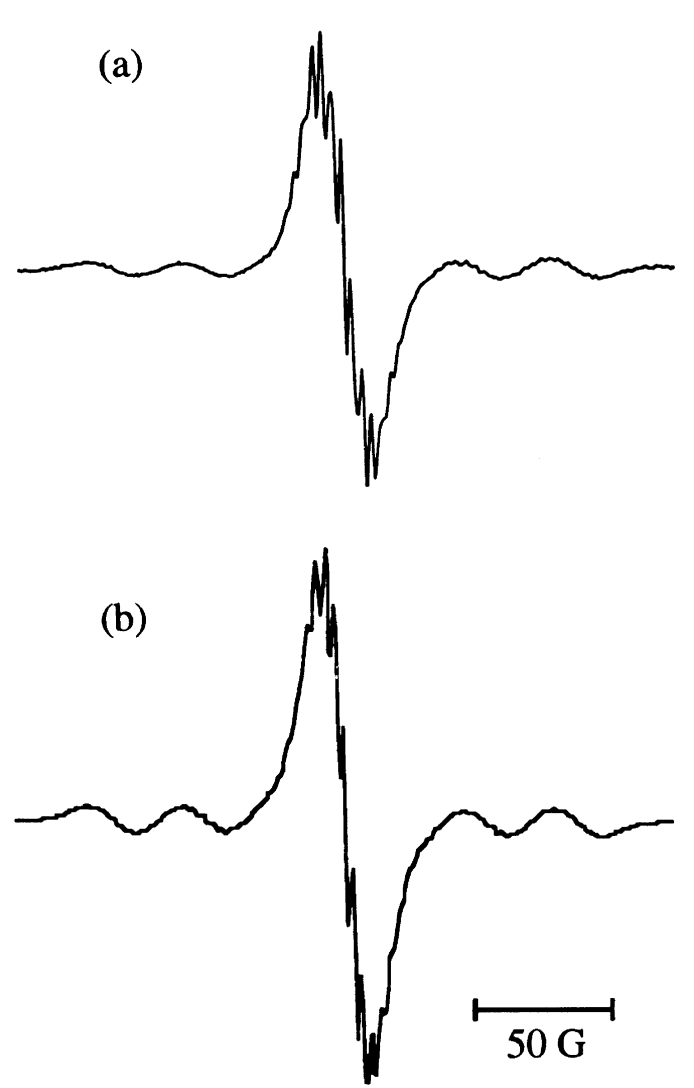

Fig. 1. Experimental (top) and simulated (bottom) EPR spectrum for compound $\mathbf{1}$ (solvent $=\mathrm{THF}, \mathrm{T}=-100^{\circ} \mathrm{C}$ ).

Neither does 3 react with a large excess of butadiene at room temperature. However, treatment in neat $\mathrm{Bu}^{\mathrm{t}} \mathrm{NC}$ leads to the smooth formation of the diamagnetic compound $\mathrm{CpMo}\left(\eta-\mathrm{C}_{3} \mathrm{H}_{5}\right)\left(\mathrm{CNBu}^{\mathrm{t}}\right)_{2}, \mathbf{4}$, see eq. (2).

$$
\begin{aligned}
\mathrm{CpMo}\left(\eta-\mathrm{C}_{3} \mathrm{H}_{5}\right)_{2}+ & \mathrm{Bu}^{\mathrm{t}} \mathrm{NC}(\text { excess }) \\
& \rightarrow \mathrm{CpMo}\left(\eta-\mathrm{C}_{\mathbf{4}} \mathrm{H}_{5}\right)\left(\mathrm{CNBu}^{\mathrm{t}}\right)_{2}
\end{aligned}
$$

The reaction is relatively slow, starting material being still present after several hours at room temperature. NMR spectroscopy shows the initial selective formation of $\mathbf{4}$. Prolonged exposure to the $\mathrm{Bu}^{\mathrm{t}} \mathrm{NC}$ solvent, however, results in the formation of a new diamagnetic material that shows only resonances for the $\mathrm{Cp}$ ligand and for the tert-Bu group, thus indicating decomposition of $\mathbf{4}$ with loss of the residual allyl ligand. This by-product is different from $\left[\mathrm{CpMo}\left(\mathrm{CNBu}^{\mathrm{t}}\right)_{4}\right]^{+}$(vide infra) and was not further characterized. Its formation did not permit the isolation of compound $\mathbf{4}$ in an analytically pure form. The identity of $\mathbf{4}$, however, is established by ${ }^{1} \mathrm{H}$ NMR. The allyl proton chemical shifts and coupling pattern are consistent with a supine coordination mode. In particular, the indiscernible geminal coupling between syn and anti protons is a clear indication of the supine conformation of the allyl ligand [2, 13-15].

\section{(c) Reaction of $\left[\mathrm{CpMo}\left(\eta-\mathrm{C}_{3} \mathrm{H}_{5}\right)\left(\eta-\mathrm{C}_{4} \mathrm{H}_{6}\right)\right]^{+}$with nucleo-} philes

The reaction between complex $[\mathbf{1 b}]^{+}$and $\mathrm{Bu}^{\mathrm{t}} \mathrm{NC}$ follows the same path observed for compound $\mathbf{3}$, namely reduction with formal expulsion of an allyl radical, see eq. (3). Compound $\mathbf{5}$ has previously been obtained by $\mathrm{HBF}_{4}$ protonation of $\mathbf{1 a}$ in the presence of $\mathrm{Bu}^{\mathrm{t}} \mathrm{NC}$ and fully characterized [3]. As established above for compound $\mathbf{3}$, no reaction is observed between $[\mathbf{1 b}]^{+}$and $\mathrm{MeCN}$ or butadiene under mild conditions.

$$
\begin{array}{r}
{\left[\mathrm{CpMo}\left(\eta-\mathrm{C}_{3} \mathrm{H}_{5}\right)\left(\eta-\mathrm{C}_{4} \mathrm{H}_{6}\right)\right]^{+}+\mathrm{Bu}^{\mathrm{t}} \mathrm{NC}(\text { excess }) \rightarrow} \\
{\left[\mathrm{CpMo}\left(\eta-\mathrm{C}_{4} \mathrm{H}_{6}\right)\left(\mathrm{CNBu}^{\mathrm{t}}\right)_{2}\right]^{+}}
\end{array}
$$

The existence of bisallyl Mo(III) complexes such as 3, and the established nucleophilic attack by carbanions on Mo(II)-coordinated diene ligands to afford allyl complexes, made us wonder whether the same reactivity could be observed for the Mo(III)coordinated diene ligand. Indeed, reaction of $[\mathbf{1 b}]^{+}$ with methyllithium in THF generates a new EPRactive complex which is formulated as $\operatorname{CpMo}(\eta$ $\left.\mathrm{C}_{3} \mathrm{H}_{5}\right)\left(\eta-\mathrm{C}_{3} \mathrm{H}_{4} \mathrm{Et}\right)$, 6. This nucleophilic addition process, however, corresponds to a minor reaction pathway ( $4 \%$ according to the intensity of the doubleintegrated EPR signal). The main product of the reaction, compound 1 [2], derives from a single electron transfer process (see eq. (4)). As expected from the previously reported investigation of the reduction of $[\mathbf{1 b}]^{+}[2]$, the kinetically controlled reduction product is $\mathrm{CpMo}\left(\right.$ supine- $\left.\eta-\mathrm{C}_{3} \mathrm{H}_{5}\right)\left(\right.$ supine- $\left.\eta-\mathrm{C}_{4} \mathrm{H}_{6}\right), \mathbf{1 b}$, followed by the slow isomerization to the thermodynamically favored $\mathrm{CpMo}\left(\right.$ prone- $\left.\eta-\mathrm{C}_{3} \mathrm{H}_{5}\right)\left(\right.$ supine- $\left.\eta-\mathrm{C}_{4} \mathrm{H}_{6}\right)$, 1 a.

$$
\begin{gathered}
{\left[\mathrm{CpMo}\left(\eta-\mathrm{C}_{3} \mathrm{H}_{5}\right)\left(\eta-\mathrm{C}_{4} \mathrm{H}_{6}\right)\right]^{+}+\mathrm{MeLi}} \\
\rightarrow \operatorname{CpMo}\left(\eta-\mathrm{C}_{3} \mathrm{H}_{5}\right)\left(\eta-\mathrm{C}_{4} \mathrm{H}_{6}\right) \\
\quad+\underset{\mathbf{1}}{\mathbf{6 p M o}\left(\eta-\mathrm{C}_{3} \mathrm{H}_{5}\right)\left(\eta-\mathrm{C}_{3} \mathrm{H}_{4} \mathrm{Et}\right)}
\end{gathered}
$$

The nature of the paramagnetic product as $\mathbf{6}$ is supported by the results of a protonation study of the 1/6 mixture in $\mathrm{C}_{6} \mathrm{D}_{6}$ with $\mathrm{HBF}_{4} \mathrm{Et}_{2} \mathrm{O}$. The ${ }^{1} \mathrm{H}-\mathrm{NMR}$ of the organic phase shows the formation of cis- and trans-2-pentene in a relative 2:1 ratio, in addition to propene, see eq. (5). There is no observable formation of 1-pentene from this reaction. The formation of propene by protonation of $\mathbf{1}$ has previously been studied in detail [3]. 


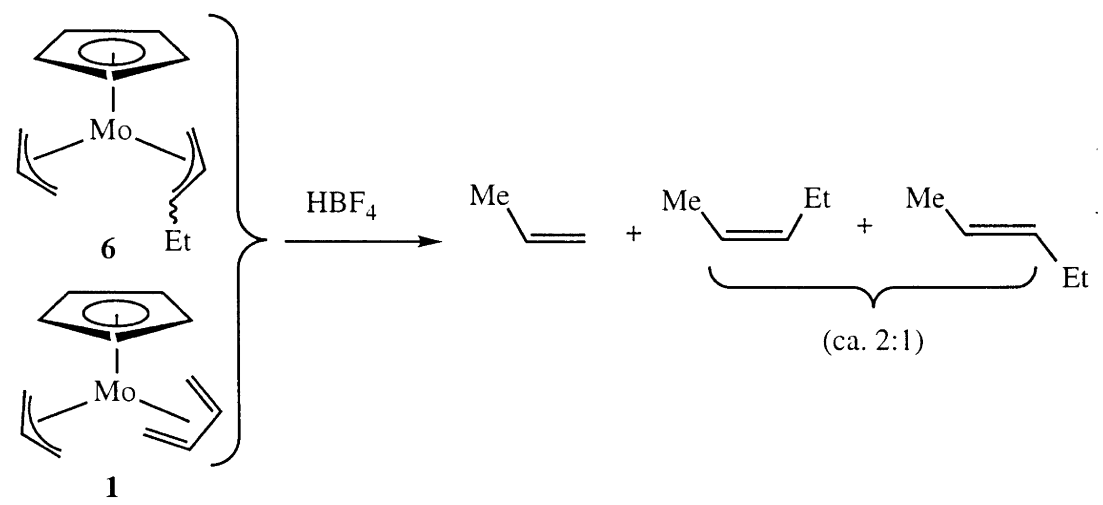

\section{(d) Oxidation of $\mathrm{CpMo}\left(\eta-\mathrm{C}_{3} \mathrm{H}_{5}\right)_{2}$}

While compound $\mathbf{3}$ is stable in acetone and $\mathrm{MeCN}$ at room temperature, oxidation with $\mathrm{Cp}_{2} \mathrm{Fe}^{+}$in either solvent induces an immediate allyl-allyl coupling and release of free 1,5-hexadiene (see eq. (6). The fate of the $\left[\mathrm{CpMo}^{+}\right]$fragment is unknown but probably leads to paramagnetic products, since no resonances attributable to the $\mathrm{Cp}$ ligand are observed in the ${ }^{1} \mathrm{H}$ NMR spectrum.

$$
\begin{aligned}
\mathrm{CpMo}\left(\eta-\mathrm{C}_{3} \mathrm{H}_{5}\right)_{2} & +\mathrm{Cp}_{2} \mathrm{Fe}^{+} \mathrm{PF}_{6}^{-} \\
\rightarrow & \mathrm{CH}_{2}=\mathrm{CHCH}_{2} \mathrm{CH}_{2} \mathrm{CH}=\mathrm{CH}_{2}
\end{aligned}
$$

When the oxidation reaction is carried out in the presence of $\mathrm{Bu}^{t} \mathrm{NC}$ as a trapping agent, two products are observed in a ca. 2:1 ratio (eq. (7). The predominant product is $\left[\mathrm{CpMo}\left(\mathrm{CNBu}^{\mathrm{t}}\right)_{3}\left(\eta^{2}-\mathrm{CH}_{2}=\right.\right.$ $\left.\left.\mathrm{CHCH}_{2} \mathrm{CH}_{2} \mathrm{CH}=\mathrm{CH}_{2}\right)\right]^{+} \mathrm{PF}_{6}^{-}$, 7. This compound could not be obtained as a pure crystalline material because the minor product, compound $\left[\mathrm{CpMo}\left(\mathrm{CNBu}^{\mathrm{t}}\right)_{4}\right]^{+} \mathrm{PF}_{6}^{-}, \mathbf{8}$, crystallizes preferentially. The latter compound has previously been obtained by a different synthetic method [16]. The NMR properties show the equivalence of the four $\mathrm{Bu}^{\mathrm{t}} \mathrm{NC}$ ligands as expected for the ubiquitous four-legged piano stool geometry, while the three IR bands observed in the $\mathrm{CN}$ stretching region are consistent with the expected $\mathrm{C}_{4 \mathrm{v}}$ local symmetry $\left(\mathrm{A}_{1}+\mathrm{B}_{1}+\mathrm{E}\right)$.

$\mathrm{CpMo}\left(\eta-\mathrm{C}_{3} \mathrm{H}_{5}\right)_{2}+\mathrm{Cp}_{2} \mathrm{Fe}^{+} \mathrm{PF}_{6}{ }^{-}+\mathrm{Bu}^{\mathrm{t}} \mathrm{NC}($ excess $) \rightarrow$ $\left[\mathrm{CpMo}\left(\mathrm{CNBu}^{\mathrm{t}}\right)_{3}\right.$

$$
\begin{gathered}
\left.\left(\eta^{2}-\mathrm{CH}_{2}=\mathrm{CHCH}_{2} \mathrm{CH}_{2} \mathrm{CH}=\mathrm{CH}_{2}\right)\right]^{+} \mathrm{PF}_{6}^{-} \\
7 \\
+\left[\mathrm{CpMo}\left(\mathrm{CNBu}^{t}\right)_{4}\right]^{+} \mathrm{PF}_{6}^{-} \\
\mathbf{8}
\end{gathered}
$$

The identification of compound 7 rests on the ${ }^{1} \mathrm{H}$ and ${ }^{13} \mathrm{C}$ NMR properties. Unlike 8, which has four equivalent tert-butyl isocyanide ligands, complex 7 has three inequivalent isocyanide ligands because of the low symmetry. All 10 protons of the coordinated 1,5-hexadiene ligand are visible in the ${ }^{1} \mathrm{H}$ NMR spectrum. The proton nomenclature is as shown in I. All assignments have been confirmed by selective homonuclear decoupling experiments, which also assisted in the determination of the coupling constants. The proton resonances of the dangling vinyl group show typical chemical shifts and coupling pattern. The coordinated vinyl group, on the other hand, exhibits resonances at higher field. The methylene protons adjacent to the coordinated vinyl group $\left(\mathrm{H}_{\mathrm{d}}\right.$ and $\left.\mathrm{H}_{\mathrm{e}}\right)$ show distinct resonances, while the other methylene protons $\left(\mathrm{H}_{\mathrm{f}}\right)$ are chemically equivalent $(2.30 \mathrm{ppm})$. Echoing the proton NMR data, the ${ }^{13} \mathrm{C}$ NMR spectrum also shows the inequivalence of the three isocyanide ligands. While the coordinated carbon resonances are significantly different, both the methyl and the tertiary carbon atoms of the three tert-butyl groups give common resonances, indicating the insensitivity of these nuclei to the immediate chemical environment of the metal center.

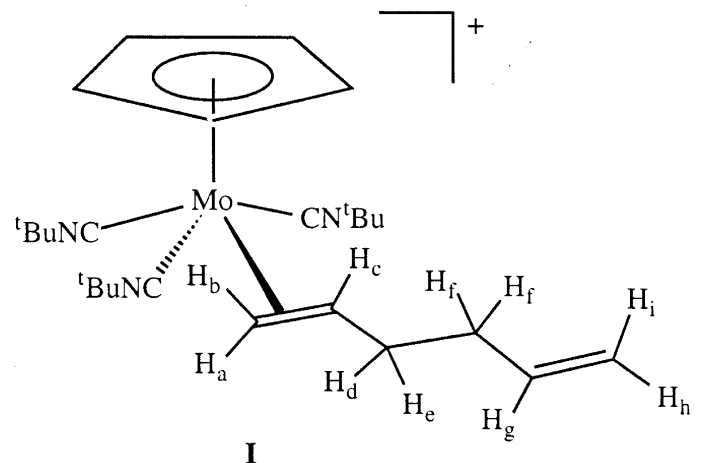

The oxidation of $\mathbf{1}$ has also been carried out in the presence of butadiene. In this case, a 2.5:1 mixture of the bisallyl $\mathrm{Mo}(\mathrm{IV})$ complex $\left[\mathrm{CpMo}\left(\eta^{3}: \eta^{3}-\mathrm{C}_{3} \mathrm{H}_{4} \mathrm{CH}_{2}\right.\right.$ $\left.\left.\left.\mathrm{CH}_{2} \mathrm{C}_{3} \mathrm{H}_{4}\right)\left(\mathrm{CD}_{3} \mathrm{CN}\right)\right]^{+} \mathrm{PF}_{6}{ }^{-}\right]$, 9, and the butadiene $\mathrm{Mo}(\mathrm{II})$ complex $\left[\mathrm{CpMo}\left(\text { supine- } \eta-\mathrm{C}_{4} \mathrm{H}_{6}\right)\left(\mathrm{CD}_{3} \mathrm{CN}\right)_{2}\right]^{+}$ $\mathrm{PF}_{6}{ }^{-}$], 10, forms after treating the reaction residue in $\mathrm{CD}_{3} \mathrm{CN}$, see eq. (8). Both complexes have previously been obtained by protonation of $1 \mathbf{c}$ in the presence of butadiene [3]. As reported previously, compound 9 is indefinitely stable in $\mathrm{CD}_{3} \mathrm{CN}$ at room temperature. A thermal study at $100^{\circ} \mathrm{C}$ in $\mathrm{CD}_{3} \mathrm{CN}$ in a sealed $\mathrm{NMR}$ tube, however, revealed its decomposition to yield 
cyclooctadiene in $70 \%$ spectroscopic yield. Free butadiene is also observed, presumably deriving from the thermal decomposition of $\mathbf{1 0}$. diene ligand but never at the s-cis butadiene or at the allyl ligands. For the Mo(III) cationic complex reported here, we have seen for the first time a nucleo-

$$
\mathrm{CpMo}\left(\eta-\mathrm{C}_{3} \mathrm{H}_{5}\right)_{2}+\mathrm{Cp}_{2} \mathrm{Fe}^{+} \mathrm{PF}_{6}{ }^{-}+\mathrm{C}_{4} \mathrm{H}_{6} \text { (excess) }
$$

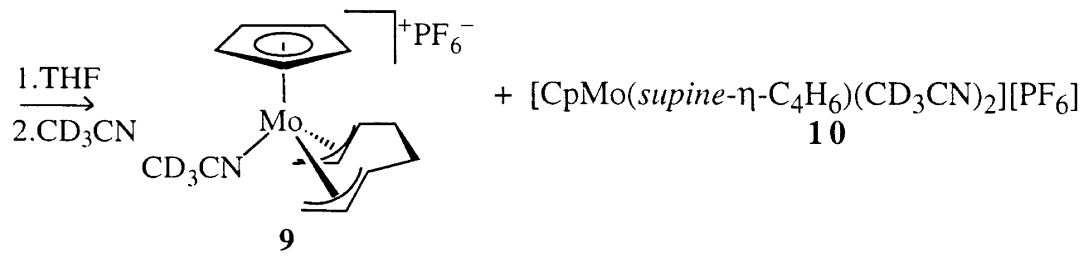

\section{DISCUSSION}

(a) Nucleophilic attack to Mo(III) vs. Mo(II)

From our previous studies, we have established that the neutral $\mathrm{Mo}(\mathrm{II})$ system $\mathrm{CpMo}\left(\eta-\mathrm{C}_{3} \mathrm{H}_{4}\right)\left(\eta-\mathrm{C}_{4} \mathrm{H}_{6}\right)$, in either of its three stable isomeric forms $(\mathbf{1 a}-\mathbf{c})$, is not susceptible to nucleophilic attack [3]. However, the cationic $\mathrm{Mo}(\mathrm{II})$ complex $\left[\mathrm{CpMo}\left(\right.\right.$ supine $\left.-\eta-\mathrm{C}_{4} \mathrm{H}_{6}\right)(s-$ trans $\left.\left.-\eta-\mathrm{C}_{4} \mathrm{H}_{6}\right)\right]^{+}, \mathbf{2}$, can be attacked by nucleophiles either at the metal (with substitution of the s-transbutadiene ligand) or at the $s$-trans-butadiene endo terminal carbon atom (with formation of an allyl derivative) [4]. For these reasons, we reasoned that a nucleophilic attack to either the metal, the butadiene ligand or the allyl ligand in the Mo(III) complexes 3 and $[\mathbf{1 b}]^{+}$might occur under the influence of the higher formal oxidation state, especially for the cationic system. As mentioned in the Introduction, no studies of the reactivity of $\mathrm{Mo}$ (III)-coordinated allyl and butadiene ligands appear to have been reported.

The results obtained show that the dominant pathway is metal reduction. The tendency of the metal to reach an 18-electron configuration, especially in the presence of $\pi$-acidic ligands, is sufficiently high to force the elimination of allyl radicals. This pathway is observed for both 3 and $[\mathbf{1 b}]^{+}$in their reaction with $\mathrm{Bu}^{\mathrm{t}} \mathrm{NC}$. It is remarkable that, for complex $[\mathbf{1 b}]^{+}$, the observed reaction pathway is more favorable than either substitution of the neutral diene ligand or insertion of the diene into the Mo(III)-allyl bond. Weaker neutral 2-electron donor such as $\mathrm{MeCN}$ do not react. The reaction of the cationic substrate with methyllithium does indeed lead to the addition product $\mathbf{6}$ (eq. (4)), but the main product is the neutral derivative $\mathbf{1 b}$ obtained from the single electron transfer pathway. This result, nevertheless, indicates an increased reactivity of the coordinated ligands on going from Mo(II) to Mo(III). For the Mo(II) complexes of the types investigated by us, a nucleophilic attack takes place (only in the cationic systems) at the s-trans buta- philic addition to the $s$-cis butadiene ligand.

The nature of the products obtained by protonating 6 (see section (c) below) indicate that this compound is a mixture of isomers with syn and anti ethylallyl ligand (2:1 in favor of the anti isomer). This mixture is probably formed by direct nucleophilic addition to the $s$-cis butadiene ligand to afford the anti allyl product, followed by partial isomerization. An alternative pathway to the syn product involving an initial isomerization to $[\mathbf{1 c}]^{+}$, followed by nucleophilic attack at the s-trans diene ligand can be excluded because, according to our previous studies [2], the thermodynamics and kinetics for the isomer interconversion reaction would not allow the formation of a significant amount of the $s$-trans isomer during the short time scale of the methylation process.

\section{(b) Allyl-allyl coupling in $\mathrm{Mo}(\mathrm{III})$ and $\mathrm{Mo}(\mathrm{IV})$}

Processes of allyl-allyl coupling in transition metal complexes are relevant as elementary steps of catalytic dimerization and oligometization of diene ligands [17]. The metal-assisted coupling of allyl ligands to afford 1,5-hexadiene products is a widely known reaction [17-19]. Previous reports for molybdenum complexes include the interaction of a "violet solution", presumably containing $\left(\eta^{6}-\mathrm{C}_{6} \mathrm{H}_{6}\right) \mathrm{Mo}\left(\eta^{3}-\mathrm{C}_{3} \mathrm{H}_{5}\right)(\mu-\mathrm{Cl})_{2} \mathrm{Al}-$ $\mathrm{ClEt}$, with propene to ultimately afford a 2,4hexadiene complex via formation of an intermediate containing coordinated 1,5-hexadiene [20]. The proposed bis(allyl) $\mathrm{Mo}(\mathrm{IV})$ intermediate, i.e. $\left[\left(\eta^{6}-\mathrm{C}_{6} \mathrm{H}_{6}\right)\right.$ $\left.\mathrm{Mo}\left(\eta^{3}-\mathrm{C}_{3} \mathrm{H}_{5}\right)_{2}\left(\mathrm{C}_{3} \mathrm{H}_{7}\right)\right]^{+}$, however, was not directly observed. More recently, the reaction of the metalmetal bonded $\mathrm{Mo}_{2}\left(\mu-\eta-\mathrm{C}_{3} \mathrm{H}_{5}\right)_{2}\left(\eta-\mathrm{C}_{3} \mathrm{H}_{5}\right)_{2}$ complex with $\mathrm{CO}$ was shown to produce $\mathrm{Mo}(\mathrm{CO})_{6}$ and 1,5-hexadiene, via an isolable $\mathrm{Mo}(\mathrm{CO})_{4}\left(\eta^{4}-1,5\right.$-hexadiene $)$ intermediate [21]. The corresponding reaction of $\mathrm{Mo}\left(\eta^{3}-\mathrm{C}_{3} \mathrm{H}_{5}\right)_{2}\left(\mathrm{PMe}_{3}\right)_{3}$ with $\mathrm{CO}$ yields $\mathrm{Mo}(\mathrm{CO})_{2}$ $\left(\mathrm{PMe}_{3}\right)_{4}$ and 1,5-hexadiene [22].

No allyl-allyl coupling process has been described for Mo(III) complexes. A spontaneous coupling has 
been reported to occur upon ligand addition to the $\mathrm{Cr}$ (III) complex $\mathrm{CpCr}\left(\eta^{3}-\mathrm{C}_{3} \mathrm{H}_{5}\right)_{2}$ [23], while the corresponding Mo complex 3 does not undergo a similar process under mild conditions [6-8], in accord with the expected greater stability of the heavier metal in the higher oxidation state. In fact, while $\sigma$-donor ligands do not react with $3, \pi$ acidic ligands induce a reductive process with loss of an allyl radical, rather than an allyl-allyl coupling, as discussed in the previous section. When compound 3 is heated in the $\sigma$ donor solvent $\mathrm{MeCN}$, however, the allyl-allyl coupling becomes possible, paralleling the reactivity of the chromium analogue.

It may be questioned whether the formation of 1,5hexadiene during the thermal decomposition of $\mathbf{3}$ in $\mathrm{MeCN}$ derives from a truly metal-assisted allyl-allyl coupling or from the coupling of free allyl radicals in solution after elimination of the latter from the coordination sphere. We have not been able to find previous studies of the allyl radical reactivity in the presence of $\mathrm{MeCN}$. We note, however, that the $\mathrm{H}$ allyl bond is stronger than the $\mathrm{H}-\mathrm{CH}_{2} \mathrm{CN}$ bond $(89 \pm 1$ and $82.3 \mathrm{kcal} / \mathrm{mol}$, respectively) [24]. This suggests that the allyl radical should preferentially abstract a $\mathrm{H}$ atom from the large excess of $\mathrm{MeCN}$ and generate propene. The ${ }^{1} \mathrm{H}$ NMR monitoring of the decomposition reaction shows the predominant formation of the coupling product $(1,5$-hexadiene:propene $=\mathrm{ca}$. $2: 1$ ), in agreement with the proposed direct allyl-allyl coupling. A thermal allyl radical elimination, however, may be competing and be responsible for the formation of propene.

Even more rapid (instantaneous at room temperature) is the elimination of 1,5-hexadiene upon oxidation of 3. No formation of propene is observed under these conditions. A hypothetical $[\mathrm{CpMo}(\eta-$ $\left.\left.\mathrm{C}_{3} \mathrm{H}_{5}\right)_{2}(\mathrm{~S})\right]^{+}$intermediate probably forms first, but its lifetime must be very short because it was not spectroscopically observed neither in acetone nor in $\mathrm{MeCN}$. It is interesting to compare this rapid $\mathrm{C}-\mathrm{C}$ coupling process with our previous findings in bisallyl $\mathrm{Mo}(\mathrm{IV})$ chemistry (Scheme 2). Complex [CpMo( $\eta$ $\left.\left.\mathrm{C}_{3} \mathrm{H}_{5}\right)\left(\eta-\mathrm{C}_{3} \mathrm{H}_{4} \mathrm{Me}\right)(\mathrm{MeCN})\right]^{+}$, which is generated by $\mathrm{HBF}_{4}$ protonation of $1 \mathrm{c}$ in $\mathrm{MeCN}$, is sufficiently stable to be observed in solution at room temperature but slowly decomposes by the same $\mathrm{C}-\mathrm{C}$ coupling process in a regioselective manner to afford 3-methyl-1,5-hexadiene [3]. Complex 9, on the other hand, is perfectly stable in $\mathrm{MeCN}$ at room temperature, whereas it eliminates cyclooctadiene upon warming to $100^{\circ} \mathrm{C}$. This elimination is also regioselective: no significant amount of the possible alternative coupling products (1,2-divinylcyclobutane and 4-vinylcyclohexene) is spectroscopically observed.

It is to be emphasized that we have no detailed information on the structure of the Mo(IV) bis-allyl materials, thus the mechanism of regiocontrol is open to speculation. Mo(IV) half-sandwich derivatives adopt pseudo-octahedral geometries with one (axial) ligand trans to the $\mathrm{Cp}$ and four (pseudo-equatorial)
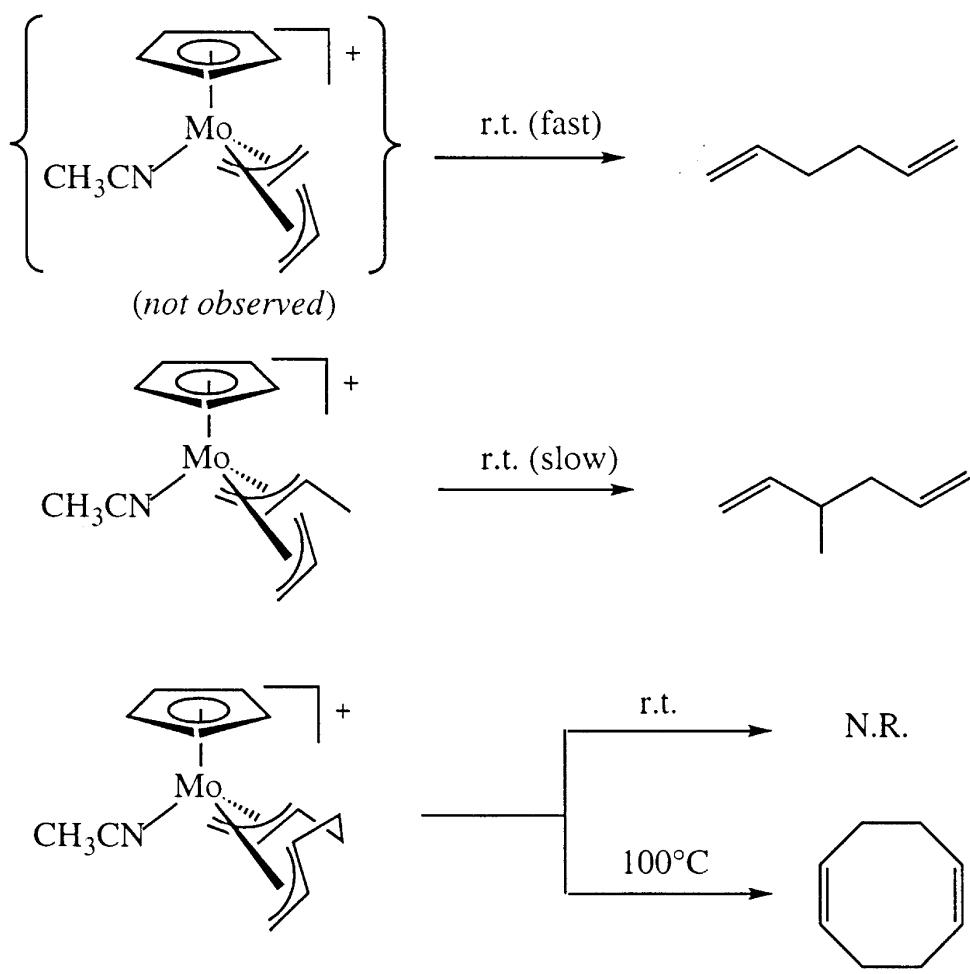

Scheme 2. 
ligands slightly deviating from the perpendicular plane away from the bulkier $\mathrm{Cp}$ ligand [25-29]. The $\mathrm{X}$-ray structure of an isoelectronic $\mathrm{CpMo}(\mathrm{CO}) \mathrm{Br}_{2}\left(\eta^{3}\right.$ $\mathrm{C}_{3} \mathrm{H}_{4}-2-\mathrm{Me}$ ) has pseudo-equatorial $\mathrm{Br}$ and $\mathrm{CO}$ ligands, whereas the allyl ligand formally occupies one pseudo-equatorial and the pseudo-axial positions [30]. On the basis of the above information, we presume that the structures of the bisally Mo(IV) derivatives are as drawn in Scheme 2.

A product of allyl-allyl coupling containing a coordinated 1,5-hexadiene is sufficiently stable and can be observed spectroscopically when the oxidation of $\mathbf{3}$ is carried out in $\mathrm{Bu}^{\mathrm{t}} \mathrm{NC}$ (compound 7). Interestingly, the 1,5-hexadiene ligand remains coordinated in a $\eta^{2}$ (monodentate) fashion to the metal center, rather than as a $\eta^{2}: \eta^{2}$ (chelating) ligand or being eliminated from the coordination sphere under the large excess of $\mathrm{Bu}^{\mathrm{t}} \mathrm{NC}$ which is present. No spectroscopic evidence was obtained for the intermediacy of a chelating hexadiene complex, which is presumed to form as shown in Scheme 3. The coordination mode is probably dictated by the electronic requirements of the metal and the balance between $\sigma$-donation and $\pi$ back-donation, a situation which is commonplace in the chemistry of carbonyl complexes. Strain in the chelated intermediate may also be responsible for the observed outcome of the reaction.

When the oxidation of $\mathbf{3}$ is carried out in the presence of excess butadiene, a similar coupling mechanism presumably takes place (Scheme 4), leading to the formation of a mixture of $\mathbf{9}$ and $\mathbf{1 0}$ after treatment with $\mathrm{CD}_{3} \mathrm{CN}$. The formation of these two products can be understood on the basis of our previous studies: coordination of two butadiene ligands in the $s$-trans mode leads to $\mathrm{C}-\mathrm{C}$ coupling; coordination of one $s$ trans and one s-cis ligands leads to the stable 2; finally, coordination of two $s$-cis ligands does not occur [3]. Complex $\mathbf{2}$ is known to exchange the s-trans butadiene ligand upon dissolution in acetonitrile [3].

\section{(c) Electrophilic reactivity of $\mathrm{Mo}(\mathrm{III})-$ bonded allyl ligands}

The protonation of the allyl ligands in compound 6 to generate 2-pentene isomers (eq. (5)) demonstrates that Mo(III)-coordinated allyl ligands are sufficiently electron-rich to be subjected to electrophilic attack by protons. The absence of any 1-pentene among the reaction products shows that the proton attacks regioselectively the unsubstituted terminal allyl position, in agreement with the electron-releasing effect of the alkyl substituent. This result is identical to what we have observed for the protonation of syn1-ethylallyl in the $\mathrm{Mo}(\mathrm{II})$ complex $\mathrm{CpMo}\left(\eta^{4}-\mathrm{C}_{4} \mathrm{H}_{6}\right)\left(\eta^{3}\right.$ syn- $\mathrm{C}_{3} \mathrm{H}_{4}-1-\mathrm{Et}$ ) [4]. In that case, only trans-2-pentene was obtained from the syn-ethylallyl ligand. Therefore, the results of the protonation of $\mathbf{6}$ indicates that this is a mixture of syn- and anti-ethylallyl isomers, with a prevalence for the anti isomer. This, in turn, indicates that the alkylation of the s-cis-supine butadiene ligand is followed by partial (either for thermodynamic or kinetic reasons) isomerization of the resulting anti-allyl ligand to the syn isomer (see Scheme 5).

\section{CONCLUSIONS}

The reactivity of allyl and diene ligands coordinated to paramagnetic Mo(III) centers has been explored for the first time. A variety of transformations have been established, including electrophilic addition to the allyl ligand, nucleophilic addition to the butadiene ligand, allyl-allyl coupling, metal reduction by singleelectron transfer or via allyl radical elimination, and metal oxidation. A few pathways have been compared with those in analogous complexes of $\mathrm{Cr}(\mathrm{III}), \mathrm{Mo}(\mathrm{II})$ and Mo(IV). The observed patterns can be summarized as follows:

1. While allyl-allyl coupling occurs spontaneously at room temperature in $\mathrm{CpCr}\left(\eta^{3}-\mathrm{C}_{3} \mathrm{H}_{5}\right)_{2}$ [23], it takes place only at higher temperatures for the Mo(III) compound 3 .

2. The $\sigma$-donor $/ \pi$-acceptor $\mathrm{Bu}^{\mathrm{t} N C}$ ligand induces reduction of both $\mathbf{3}$ and $[\mathbf{1 b}]^{+}$at room temperature, with loss of an allyl radical and formation of 18electron $\mathrm{Mo}(\mathrm{II})$ products.

3. The stronger $\sigma$-donor ligand LiMe induces a oneelectron reduction process on $[\mathbf{1 b}]^{+}$, to produce the parent complex $\mathbf{1 b}$.

4. While nucleophilic addition of $\mathrm{Me}^{-}$to a s-cis-coordinated butadiene ligand is not observed for the Mo(II) complexes 1a, $\mathbf{1 b}$ and $\mathbf{2}$, it does occur for the Mo(III) complex $[\mathbf{1 b}]^{+}$, although it does not compete effectively with the preferred reduction pathway.

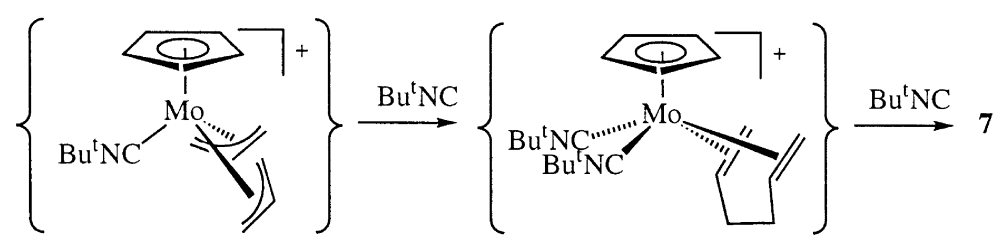

Scheme 3. 


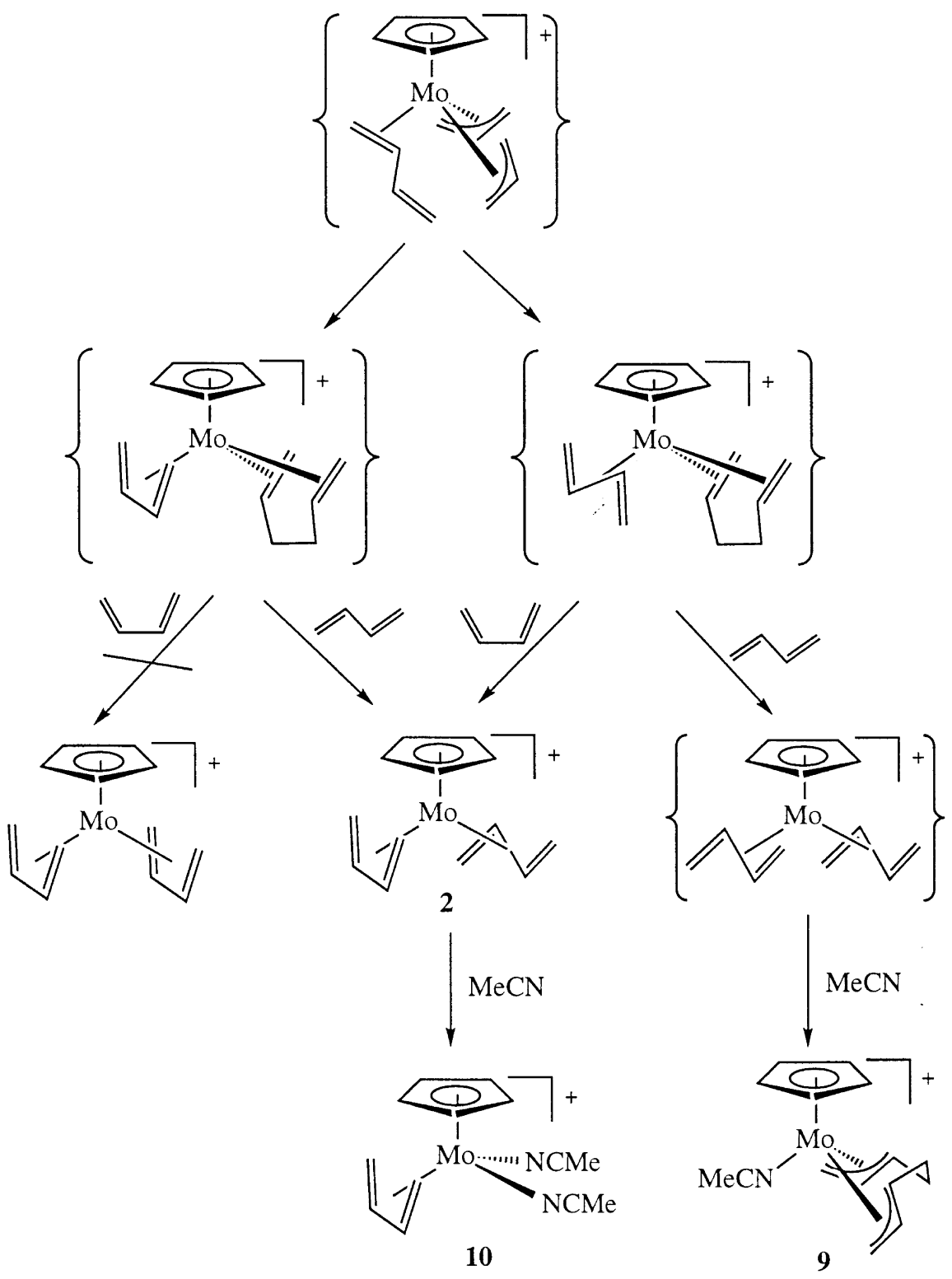

Scheme 4.

5. Protonation of the Mo(III)-bonded allyl ligands in 6 by strong acids parallels the protonation of allylmolybdenum(II) complexes, with the generation of olefins. The protonation of 1-ethylallyl occurs regioselectively to generate 2-pentenes.

6. The allyl-allyl coupling reaction is greatly accelerated by oxidation to Mo(IV). The rate of this coupling process is greatly affected by the substitution at the allyl carbons. Regioselectivity is observed for substituted allyl ligands, with the $\eta^{3}: \eta^{3}-1,1^{\prime}-\mathrm{C}_{3} \mathrm{H}_{4} \mathrm{CH}_{2} \mathrm{CH}_{2} \mathrm{C}_{3} \mathrm{H}_{4}$ ligand giving rise to cyclooctadiene as the sole coupling product.

\section{EXPERIMENTAL PROCEDURE}

General Procedures

All operations were carried out by standard Schlenk-line techniques under a dinitrogen atmosphere. Solvents were dried by conventional methods (THF and $\mathrm{Et}_{2} \mathrm{O}$ on $\mathrm{Na}$ /benzophenone, toluene and heptane on $\mathrm{Na}, \mathrm{CH}_{2} \mathrm{Cl}_{2}$ on $\mathrm{P}_{4} \mathrm{O}_{10}$ ) and distilled directly from the drying agent under dinitrogen. All routine NMR experiments were carried out on a Bruker AM400 or WF 200 spectrometers. The ${ }^{1} \mathrm{H}$ and ${ }^{13} \mathrm{C}$ NMR data of 


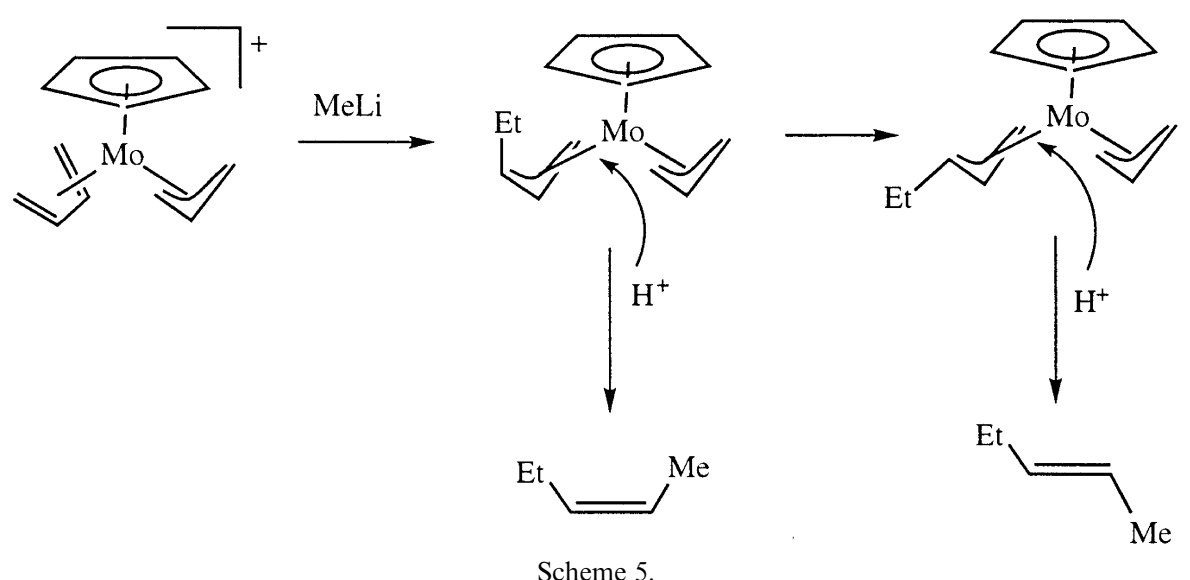

all compounds are given in Table 1. Other spectrometers used were as follows: EPR, Bruker ER200; IR, Perkin-Elmer FTIR 1600; MS, VG 7070E. Elemental analyses were performed by Atlantic Microlab, Inc. or the analytical service at the LSEO, Dijon. Compounds $\mathrm{CpMoCl}_{4}[11]$ and $[\mathbf{1 b}]\left[\mathrm{PF}_{6}\right]$ [2] were prepared according to the literature.

\section{Preparation of $\mathrm{CpMo}\left(\eta-\mathrm{C}_{3} \mathrm{H}_{5}\right)_{2}, 3$}

To a diethyl ether solution of allylmagnesium chloride $(66 \mathrm{~mL}, 1 \mathrm{M}, 66 \mathrm{mmol})$ was added $60 \mathrm{~mL}$ of THF at $-78^{\circ} \mathrm{C}$. Solid $\mathrm{CpMoCl}_{4}(4.5 \mathrm{~g}, 14.9 \mathrm{mmol})$ was added to the solution over $15 \mathrm{~min}$, causing the precipitation of a yellow solid. The suspension was stirred for $1 \mathrm{~h}$ at $-78^{\circ} \mathrm{C}$ and then an additional hour at $0^{\circ} \mathrm{C}$. All solvent was evacuated and the solid was dried overnight under vacuum. The product was extracted with heptane $(2 \times 100 \mathrm{~mL})$, each washing being stirred for $1 \mathrm{~h}$ to ensure maximum extraction. The combined filtered extracts were evaporated to dryness under reduced pressure. The residue was redissolved in $150 \mathrm{~mL}$ of heptane, leaving a small amount of undissolved grey solid which was filtered off. The solvent was removed again by evaporation and the residue

Table 1. ${ }^{1} \mathrm{H}-\mathrm{NMR}$ data

\begin{tabular}{|c|c|c|}
\hline Compd & ${ }^{1} \mathrm{H}-\mathrm{NMR}(\delta)$ & ${ }^{13} \mathrm{C}-\mathrm{NMR}(\delta)$ \\
\hline $\begin{array}{l}\mathrm{CpMo}\left(\text { supine- } \eta-\mathrm{C}_{3} \mathrm{H}_{5}\right)\left(\mathrm{CNBu}^{t}\right)_{2} \\
(\mathbf{4})^{\mathrm{a}}\end{array}$ & $\begin{array}{l}4.95(5 \mathrm{H}, \mathrm{Cp}, \mathrm{s}) ; 3.61\left(1 \mathrm{H}_{\mathrm{d}}, \mathrm{tt}\right. \\
\left.{ }^{3} \mathrm{~J}_{\mathrm{HHe}}=5 \mathrm{~Hz},{ }^{3} \mathrm{~J}_{\mathrm{HHf}}=7 \mathrm{~Hz}\right) ; 2.37\left(2 \mathrm{H}_{\mathrm{e}}, \mathrm{d},\right. \\
\left.{ }^{3} \mathrm{~J}_{\mathrm{HHd}}=5 \mathrm{~Hz}\right) ; 1.57\left(1 \mathrm{H}_{\mathrm{f}}, \mathrm{d},{ }^{3} \mathrm{~J}_{\mathrm{HHd}}=7 \mathrm{~Hz}\right) \\
1.13\left(18 \mathrm{H}, 2 \mathrm{CNBu}^{t}\right)\end{array}$ & \\
\hline $\begin{array}{l}{\left[\mathrm{CpMo}\left(\eta^{2}-\mathrm{CH}_{2}=\mathrm{CHCH}_{2}-\right.\right.} \\
\left.\left.\mathrm{CH}_{2} \mathrm{CH}=\mathrm{CH}_{2}\right)\left(\mathrm{CNBu}^{\mathrm{t}}\right)_{3}\right]\left[\mathrm{PF}_{6}\right] \\
(7)^{\mathrm{b}}\end{array}$ & $\begin{array}{l}5.89\left(1 \mathrm{H}_{\mathrm{g}}, \mathrm{ddt},{ }^{3} \mathrm{~J}_{\mathrm{HHi}}=16 \mathrm{~Hz},{ }^{3} \mathrm{~J}_{\mathrm{HHh}}=9 \mathrm{~Hz},\right. \\
\left.{ }^{3} \mathrm{~J}_{\mathrm{HHf}}={ }^{3} \mathrm{~J}_{\mathrm{HHf}}=13 \mathrm{~Hz}\right), 5.00\left(1 \mathrm{H}_{\mathrm{i}}, \mathrm{ddt},\right. \\
{ }^{3} \mathbf{J}_{\mathrm{HHg}}=16 \mathrm{~Hz},{ }^{2} \mathbf{J}_{\mathrm{HHh}}=2 \mathrm{~Hz}, \\
\left.{ }^{4} \mathrm{~J}_{\mathrm{HHf}}=1.5 \mathrm{~Hz}\right), 4.94(5 \mathrm{H}, \mathrm{s}, \mathrm{Cp}), 4.93 \\
\left(1 \mathrm{H}_{\mathrm{h}}, \mathrm{ddt},{ }^{3} \mathrm{~J}_{\mathrm{HHg}}=9 \mathrm{~Hz},{ }^{2} \mathrm{~J}_{\mathrm{HHi}}=2 \mathrm{~Hz},\right. \\
\left.{ }^{4} \mathrm{~J}_{\mathrm{HHf}}=1 \mathrm{~Hz}\right), 2.92\left(1 \mathrm{H}_{\mathrm{c}}, \mathrm{dddd},\right. \\
{ }^{3} \mathrm{~J}_{\mathrm{HHb}}=9 \mathrm{~Hz},{ }^{3} \mathrm{~J}_{\mathrm{HHa}}=12 \mathrm{~Hz},{ }^{3} \mathrm{~J}_{\mathrm{HHd}}=10 \mathrm{~Hz}, \\
\left.{ }^{3} \mathrm{~J}_{\mathrm{HHe}}=4 \mathrm{~Hz}\right), 2.30\left(2 \mathrm{H}_{\mathrm{f}}, \mathrm{m}\right), 1.99\left(1 \mathrm{H}_{\mathrm{b}},\right. \\
\left.\mathrm{dd},{ }^{3} \mathrm{~J}_{\mathrm{HHc}}=9 \mathrm{~Hz},{ }^{3} \mathrm{~J}_{\mathrm{HHa}}=3 \mathrm{~Hz}\right), 1.99(1 \mathrm{Hd}, \\
\mathrm{m}) 1.73\left(1 \mathrm{H}_{\mathrm{a}}, \mathrm{dd},{ }^{3} \mathrm{~J}_{\mathrm{HHc}}=12 \mathrm{~Hz},\right. \\
\left.{ }^{3} \mathbf{J}_{\mathrm{HHb}}=3 \mathrm{~Hz}\right), 1.50(9 \mathrm{H}, \mathrm{CNBu}), \sim 1.4 \\
(1 \mathrm{He}, \text { overlapping with CNBut }), 1.40(9 \mathrm{H}, \\
\mathrm{CNBu}), 1.37\left(9 \mathrm{H}, \mathrm{CNBu}{ }^{\mathrm{t}}\right)\end{array}$ & $\begin{array}{l}168.1\left(1 \mathrm{C}, \mathrm{s}, \underline{\mathrm{CNC}}\left(\mathrm{CH}_{3}\right)_{3}\right), 164.3(1 \mathrm{C}, \mathrm{s}, \\
\left.\underline{\mathrm{CNC}}\left(\mathrm{CH}_{3}\right)_{3}\right), 162.4\left(1 \mathrm{C}, \mathrm{s}, \underline{\mathrm{CNC}}\left(\mathrm{CH}_{3}\right)_{3}\right), \\
{ }^{140.0}\left(1 \mathrm{C}_{\mathrm{g}}, \mathrm{d},{ }^{1} J_{\mathrm{CH}}=155 \mathrm{~Hz}\right), 114.6\left(1 \mathrm{C}_{\mathrm{hi}},\right. \\
\left.\mathrm{t},{ }^{1} J_{\mathrm{CH}}=155 \mathrm{~Hz}\right), 88.9(5 \mathrm{C}, \mathrm{d}, \\
\left.{ }^{1} J_{\mathrm{CH}}=181 \mathrm{~Hz}\right), 68.8\left(1 \mathrm{C}_{\mathrm{c}}, \mathrm{d},\right. \\
\left.{ }^{1} J_{\mathrm{CH}}=176 \mathrm{~Hz}\right), 59.2(3 \mathrm{C}, \mathrm{b}, \\
\left.\mathrm{CNC}\left(\mathrm{CH}_{3}\right)_{3}\right), 41.4\left(1 \mathrm{C}_{\mathrm{fr}} \text { or } 1 \mathrm{C}_{\mathrm{de}}, \mathrm{t},\right. \\
\left.{ }^{1} J_{\mathrm{CH}}=120 \mathrm{~Hz}\right), 40.4\left(1 \mathrm{C}_{\mathrm{de}} \text { or } 1 \mathrm{C}_{\mathrm{fr}}, \mathrm{t},\right. \\
\left.{ }^{1} J_{\mathrm{CH}}=120 \mathrm{~Hz}\right), 30.4(9 \mathrm{C}, \text { quartet, } \\
\left.\left.{ }^{1} J_{\mathrm{CH}}=128 \mathrm{~Hz}, \mathrm{CNC}(\underline{\mathrm{C}})_{3}\right)_{3}\right), \sim 30\left(1 \mathrm{C}_{\mathrm{ab}},\right. \\
\left.\text { overlapping with } \mathrm{CNC}\left(\underline{\mathrm{CH}}_{3}\right)_{3}\right)\end{array}$ \\
\hline$\left[\mathrm{CpMo}\left(\mathrm{CNBu}^{\mathrm{t}}\right)_{4}\right]\left[\mathrm{PF}_{6}\right](\mathbf{8})^{\mathrm{b}}$ & $5.10(5 \mathrm{H}, \mathrm{s}, \mathrm{Cp}), 1.46\left(36 \mathrm{H}, \mathrm{s}, \mathrm{CNC}\left(\mathrm{CH}_{3}\right)_{3}\right)$ & $\begin{array}{l}174.0\left(4 \mathrm{C}, \mathrm{s}, \underline{\mathrm{CNC}}\left(\mathrm{CH}_{3}\right)_{3}\right), 90.1(5 \mathrm{C}, \mathrm{d}, \\
\left.{ }^{1} J=177 \mathrm{~Hz}, \mathrm{Cp}\right), 59.3(4 \mathrm{C}, \mathrm{s} \\
\left.\mathrm{CNC}\left(\mathrm{CH}_{3}\right)_{3}\right), 31.1(12 \mathrm{C}, \text { quartet, } \\
\left.{ }^{1} J=128 \mathrm{~Hz}, \mathrm{CNC}\left(\underline{C H}_{3}\right)_{3}\right)\end{array}$ \\
\hline
\end{tabular}

(a) $\mathrm{C}_{6} \mathrm{D}_{6}$; (b) acetonitrile- $\mathrm{d}_{3}$. 
was recrystallized from heptane at $-80^{\circ} \mathrm{C}$, yielding a violet microcrystalline solid which was dried under vacuum for $2 \mathrm{~h}$ (yield $1.6 \mathrm{~g}, 44 \%$ ). Anal. Calcd for $\mathrm{C}_{11} \mathrm{H}_{15} \mathrm{Mo}$ : C, 54.32; H, 6.17. Found: C, 54.05; H, 6.04. The solid has a dichroic behavior. Powder and small crystals appear violet to reflected light but orange to transmitted light. Larger crystals are orange as previously reported [6]. The solid is extremely air sensitive, turning immediately black upon exposure to the laboratory atmosphere. EPR (THF, $-100^{\circ} \mathrm{C}$ ): $g=2.032, a_{\mathrm{Mo}}=33 \mathrm{G}, a_{4 \mathrm{H}}=6.6 \mathrm{G}, a_{4 \mathrm{H}}=3.3 \mathrm{G}$. EPR (THF or benzene, room temperature): broad singlet at $g=2.028$ with Mo satellites, $\mathrm{a}_{\mathrm{Mo}}=33 \mathrm{G}$.

Reaction of 3 with tert-butyl isocyanide. Formation of $\mathrm{CpMo}\left(\right.$ supine- $\left.\eta-\mathrm{C}_{3} \mathrm{H}_{5}\right)\left(\mathrm{CNBu}^{t}\right)_{2}, 4$

Compound $1(10 \mathrm{mg}, 41 \mu \mathrm{mol})$ was placed in a NMR tube together with $250 \mu \mathrm{L}$ of $\mathrm{Bu}^{\mathrm{t}} \mathrm{NC}$. Standing at room temperature overnight yielded a maroon solution. The excess of tert-butyl isocyanide was removed under reduced pressure and $0.5 \mathrm{~mL}$ of $\mathrm{C}_{6} \mathrm{D}_{6}$ was added. The ${ }^{1} \mathrm{H}$ NMR spectrum showed the formation of compound 4, while the EPR spectrum indicated the presence of the unreacted starting complex 3. The separation of these two complexes was not successful. When the experiment was repeated with longer standing in $\mathrm{Bu}^{\mathrm{t}} \mathrm{NC}$, decomposition of $\mathbf{4}$ occurred to generate another species with the $\mathrm{Cp}$ resonance at $\delta 5.36$ in $\mathrm{C}_{6} \mathrm{D}_{6}$ and another resonance at $\delta 1.30$, assigned to $\mathrm{Bu}^{\mathrm{t}}$ groups. No allyl resonances are observed for this species.

Reaction of $[1 \mathrm{~b}]\left[\mathrm{PF}_{6}\right]$ with tert-butyl isocyanide. Formation of $\left[\mathrm{CpMo}\left(\right.\right.$ supine $\left.\left.-\eta-\mathrm{C}_{4} \mathrm{H}_{6}\right)(\mathrm{CNBu} t)_{2}\right]\left[\mathrm{PF}_{6}\right], 5$

Compound [1 $\mathbf{1 b}]\left[\mathrm{PF}_{6}\right](10 \mathrm{mg}, 25 \mu \mathrm{mol})$ was mixed with $\mathrm{Bu}^{\mathrm{t}} \mathrm{NC}(100 \mu \mathrm{L}, 0.885 \mathrm{mmol})$ in a NMR tube Upon heating to $60^{\circ} \mathrm{C}$ for $10 \mathrm{~min}$, a yellow solution was formed, accompanied by a black precipitate. The solution was centrifuged and the supernatant was transferred into another NMR tube via cannula. After removal of excess tert-butylisocyanide under reduced pressure, a yellow oil was obtained. A ${ }^{1} \mathrm{H}$ NMR spectrum in $\mathrm{CDCl}_{3}$ showed resonances at $\delta 5.56(\mathrm{~m}, 2 \mathrm{H})$, $5.10(s, 5 \mathrm{H}), 2.32(d, 2 \mathrm{H}), 1.45(s, 18 \mathrm{H}), 1.00(d, 2 \mathrm{H})$, which are attributed to the cation of 5 by comparison with the literature [3], in addition to two unidentified species with the $\mathrm{Cp}$ resonances at $\delta 5.03$ and 4.96 . Integration showed a 61:16:23 ratio of the three products. No EPR active species were detected.

Reaction of $[1 \mathrm{~b}]\left[\mathrm{PF}_{6}\right]$ with MeLi. Formation of $\mathrm{CpMo}\left(\eta-\mathrm{C}_{3} \mathrm{H}_{5}\right)\left(\eta-\mathrm{C}_{4} \mathrm{H}_{6}\right), \quad \mathbf{1}$, and $\mathrm{CpMo}\left(\eta-\mathrm{C}_{3} \mathrm{H}_{5}\right)(\eta-$ $\left.\mathrm{C}_{3} \mathrm{H}_{4} \mathrm{Et}\right), 6$

Compound [1b] $\left.\mathbf{1} \mathrm{PF}_{6}\right](60 \mathrm{mg}, 0.15 \mathrm{mmol})$ was suspended in $20 \mathrm{~mL}$ of THF. MeLi $(107 \mu \mathrm{L}, 1.4 \mathrm{M}$ in
$\mathrm{Et}_{2} \mathrm{O}, 0.15 \mathrm{mmol}$ ) was added by syringe, causing the formation of a red solution. After stirring at room temperature for $1 \mathrm{~h}$, all solvent was removed by evaporation under reduced pressure and the residue was extracted with $20 \mathrm{~mL}$ of heptane. After filtration, the solution was evaporated to dryness under reduced pressure, giving a red solid (yield $25 \mathrm{mg}$ ). The ${ }^{1} \mathrm{H}$ NMR spectrum in $\mathrm{C}_{6} \mathrm{D}_{6}$ showed resonances of $\mathrm{Cp}$ at $\delta 4.10$ and 4.27 in a ca. $4: 1$ ratio, which are attributed to $\mathrm{CpMo}\left(\right.$ supine $\left.-\eta-\mathrm{C}_{3} \mathrm{H}_{5}\right)\left(\right.$ supine $\left.-\eta-\mathrm{C}_{4} \mathrm{H}_{6}\right) \quad$ (1b) and $\mathrm{CpMo}\left(\right.$ prone- $\left.\eta-\mathrm{C}_{3} \mathrm{H}_{5}\right)$ (supine- $\left.\eta-\mathrm{C}_{4} \mathrm{H}_{6}\right) \quad$ (1a), respectively, by comparison with the literature [2]. Continued monitoring of this solution showed the slow conversion of $\mathbf{1 b}$ to $1 \mathbf{a}$ according to the previous report [2]. An EPR study of the $\mathrm{C}_{6} \mathrm{D}_{6}$ solution showed an unresolved multiplet resonance at $g=2.033$, $a_{\mathrm{Mo}}=33 \mathrm{G}$, which is assigned to compound 6 . Double integration of the EPR resonance against that of the starting material gives a $4 \%$ yield of the paramagnetic species.

Protonation of the mixture of $\mathrm{CpMo}\left(\eta-\mathrm{C}_{3} \mathrm{H}_{5}\right)\left(\eta-\mathrm{C}_{4} \mathrm{H}_{6}\right)$ (1a and 1b) and $\mathrm{CpMo}\left(\eta-\mathrm{C}_{3} \mathrm{H}_{5}\right)\left(\eta-\mathrm{C}_{3} \mathrm{H}_{4} \mathrm{Et}\right), \mathbf{6}$

The mixture of complex $\mathbf{1}$ and $\mathbf{6}$ obtained by the procedure described in the previous section $(10 \mathrm{mg})$ was dissolved in $0.5 \mathrm{~mL}$ of $\mathrm{C}_{6} \mathrm{D}_{6}$ in an NMR tube. $\mathrm{HBF}_{4} \cdot \mathrm{Et}_{2} \mathrm{O}(10 \mu \mathrm{L}$, excess) was added, causing the immediate formation of a grey precipitate. The supernatant was transferred into another NMR tube by vacuum condensation. The ${ }^{1} \mathrm{H}$ NMR spectrum showed the formation of both cis-2-pentene and trans2-pentene with a ratio of ca. 2:1, in addition to the signals of propene. The products were identified by analysis of the olefinic proton resonances, in comparison with those reported in the literature [31]. The other aliphatic resonances overlap extensively. ${ }^{1} \mathrm{H}$ NMR of cis-2-pentene $\left(\delta, \mathrm{C}_{6} \mathrm{D}_{6}\right): 5.37(\mathrm{~m}), 1.95(\mathrm{~m})$, $1.55(\mathrm{~m}), 1.08$ (overlap with large $\mathrm{Et}_{2} \mathrm{O}$ resonance). ${ }^{1} \mathrm{H}$ NMR of trans-2-pentene $\left(\delta, \mathrm{C}_{6} \mathrm{D}_{6}\right): 5.47(m, 2 \mathrm{H}), 1.95$ $(m), 1.55(m), 1.08$ (overlap with large $\mathrm{Et}_{2} \mathrm{O}$ resonance). ${ }^{1} \mathrm{H}$ NMR of propene $\left(\delta, \mathrm{C}_{6} \mathrm{D}_{6}\right): 5.70(m, 1 \mathrm{H})$, $4.99(\mathrm{dm}, 1 \mathrm{H}), 4.93(\mathrm{dm}, 1 \mathrm{H}), 1.53$ (overlap). No other resonances that could be attributed to a vinyl group (e.g. of 1-pentene) could be observed.

\section{Reactions of $\mathbf{3}$ with ferrocenium hexafluorophosphate}

1. In acetone- $d^{6}$. Compound $3(10 \mathrm{mg} ; 42 \mu \mathrm{mol})$ and $\mathrm{Cp}_{2} \mathrm{Fe}^{+} \mathrm{PF}_{6}^{-}(14 \mathrm{mg} ; 42 \mu \mathrm{mol})$ were mixed in an NMR tube, to which $0.5 \mathrm{~mL}$ of $\mathrm{CD}_{3} \mathrm{COCD}_{3}$ was added. The formation of 1,5-hexadiene $(\delta 5.79, \mathrm{~m}$, $2 \mathrm{H} ; 4.95, m, 4 \mathrm{H} ; 2.07, m, 4 \mathrm{H})$ and ferrocene $(\delta$ 4.15 , s) were detected by ${ }^{1} \mathrm{H}$ NMR. No significant amount of other species was found by ${ }^{1} \mathrm{H}$ NMR.

2. In acetonitrile- $d^{3}$. CpMo(supine- $\left.\eta-\mathrm{C}_{3} \mathrm{H}_{5}\right)_{2}(5 \mathrm{mg}$, $21 \mu \mathrm{mol})$ and $\mathrm{Cp}_{2} \mathrm{Fe}^{+} \mathrm{PF}_{6}^{-}(7 \mathrm{mg}, 21 \mu \mathrm{mol})$ were placed in an NMR tube, to which $0.5 \mathrm{~mL}$ of $\mathrm{CD}_{3} \mathrm{CN}$ was added. The ${ }^{1} \mathrm{H}$ NMR spectrum of the 
resulting solution showed the formation of 1,5hexadiene $(\delta 5.83, m, 2 \mathrm{H} ; 4.97, m, 4 \mathrm{H} ; 2.13, m, 4 \mathrm{H})$ and ferrocene $(\delta 4.15, \mathrm{~s})$ in a ca. $1: 1$ ratio. No significant amount of other species was detected by ${ }^{1} \mathrm{H}$ NMR, while the EPR spectrum showed several resonances with no discernible coupling pattern.

Reaction of $\mathbf{3}$ with ferrocenium hexafluorophosphate in tert-butyl isocyanide. Formation of $\left[\mathrm{CpMo}\left(\mathrm{CNBu}^{\mathrm{t}}\right)_{3}\right.$ $\left.\left(\eta \eta^{2}-\mathrm{CH}_{2}=\mathrm{CHCH}_{2} \mathrm{CH}_{2} \mathrm{CH}=\mathrm{CH}_{2}\right)\right]\left[\mathrm{PF}_{6}\right], \quad 7, \quad$ and $\left[\mathrm{CpMo}\left(\mathrm{CNBu}^{\mathrm{t}}\right)_{4}\right]\left[\mathrm{PF}_{6}\right], 8$

1. NMR tube reaction. Compound $\mathbf{3}(12 \mathrm{mg} ; 49 \mu \mathrm{mol})$ and $\mathrm{Cp}_{2} \mathrm{Fe}^{+} \mathrm{PF}_{6}{ }^{-}(17 \mathrm{mg} ; 51 \mu \mathrm{mol})$ were placed in an NMR tube, to which $100 \mu \mathrm{L}$ of $\mathrm{Bu}^{\mathrm{t}} \mathrm{NC}$ was added by syringe. The mixture was vigorously shaken for $15 \mathrm{~min} . \mathrm{C}_{6} \mathrm{D}_{6}(0.5 \mathrm{~mL})$ was then added, yielding a yellow solution. Two species with $\mathrm{Cp}$ signals at $\delta 4.85$ (complex 7) and 5.03 (complex 8) in a ca. 2:1 ratio were observed by ${ }^{1} \mathrm{H}$ NMR.

2. Isolation of compound $\mathbf{8}$. Compound $\mathbf{3}(200 \mathrm{mg}$; $0.82 \mathrm{mmol})$ and $\mathrm{Cp}_{2} \mathrm{Fe}^{+} \mathrm{PF}_{6}{ }^{-}(272 \mathrm{mg} ; 0.82 \mathrm{mmol})$ were mixed in a Schlenk tube, to which $2 \mathrm{~mL}$ of $\mathrm{Bu}^{\mathrm{t}} \mathrm{NC}$ was added. The mixture was stirred at room temperature for $0.5 \mathrm{~h}$, giving a yellow suspension. The excess $\mathrm{Bu}^{t} \mathrm{NC}$ was completely removed by evaporation under reduced. Benzene $(10 \mathrm{~mL})$ was added to the yellow residue, and the resulting suspension was stirred for $1 \mathrm{~h}$. The supernatant was decanted and the yellow solid was recrystallized from THF $(5 \mathrm{~mL})$ at $-80^{\circ} \mathrm{C}$, to yield a bright yellow crystalline solid which was recovered by filtration and dried under vacuum for $0.5 \mathrm{~h}$ (yield $85 \mathrm{mg}, 15 \%$ ). Anal. Calcd for $\mathrm{C}_{25} \mathrm{H}_{41} \mathrm{~N}_{4}$ $\mathrm{MoPF}_{6} \cdot 0.75 \mathrm{C}_{4} \mathrm{H}_{8} \mathrm{O}: \mathrm{C}, 48.56 ; \mathrm{H}, 6.84$. Found: $\mathrm{C}$, $48.31 ; \mathrm{H}, 6.80$. The THF of solvation was observed in the ${ }^{1} \mathrm{H}$ NMR spectrum in the correct integrated intensity. IR (Nujol, cm ${ }^{-1}$ ): 2162 m, 2096 s, 2050 s, 841 s (PF6). Low resolution mass spectrum $\left(\mathrm{FAB}^{+}\right): \mathrm{m} / \mathrm{z} 495\left[\mathrm{CpMo}\left(\mathrm{CNBu}^{\mathrm{t}}\right)_{4}\right]^{+}, 100 \%$.

Reaction of $\mathbf{3}$ with ferrocenium hexafluorophosphate in THF/butadiene. Formation of $\left[\mathrm{CpMo}\left(\eta^{3}: \eta^{3}-\mathrm{C}_{3} \mathrm{H}_{4} \mathrm{CH}_{2}\right.\right.$ $\left.\left.\mathrm{CH}_{2} \mathrm{C}_{3} \mathrm{H}_{4}\right)\left(\mathrm{CD}_{3} \mathrm{CN}\right) \mathrm{PF}_{6}\right], 9$ and $[\mathrm{CpMo}$ (supine- $\eta$ $\left.\left.\mathrm{C}_{4} \mathrm{H}_{6}\right)\left(\mathrm{CD}_{3} \mathrm{CN}\right)_{2}\right]\left[\mathrm{PF}_{6}\right], \mathbf{1 0}$

Complex 3 (ca. $10 \mathrm{mg}$ ) and $14 \mathrm{mg}$ of $\mathrm{Cp}_{2} \mathrm{Fe}^{+} \mathrm{PF}_{6}{ }^{-}$ were placed in a Schlenk flask. Butadiene (ca. $5 \mathrm{~mL}$ ) was condensed at $-196^{\circ} \mathrm{C}$. After stirring for $0.5 \mathrm{~h}$ at $-78^{\circ} \mathrm{C}$, THF $(5 \mathrm{~mL})$ was added and the mixture was stirred at room temperature for an additional $0.5 \mathrm{~h}$. All volatiles were removed under reduced pressure and heptane $(10 \mathrm{~mL})$ was added to the residue. An orange-red extract containing ferrocene, as shown by ${ }^{1} \mathrm{H}$ NMR, was filtered off. The residue was dried under vacuum and then redissolved in $0.5 \mathrm{~mL}$ of $\mathrm{CD}_{3} \mathrm{CN}$. A ${ }^{1} \mathrm{H}$ NMR spectrum showed the formation of two major products in a 2.5:1 ratio. These have been identified as the cations of $\mathbf{9}$ and $\mathbf{1 0}$, respectively, by com- parison with the NMR spectra reported in the literature [3]. These two main products are accompanied by several additional $\mathrm{Cp}$ containing byproducts, whose overall integrated intensity is $<30 \%$ of the total.

\section{Thermal treatment of compound 9 in $\mathrm{CD}_{3} \mathrm{CN}$}

The NMR tube containing the $\mathrm{CD}_{3} \mathrm{CN}$ solution of $\mathbf{9}$ and $\mathbf{1 0}$ obtained as described in the previous section was flame-sealed. The solution was heated to $100^{\circ} \mathrm{C}$ for $1 \mathrm{~h}$ and monitored by ${ }^{1} \mathrm{H}$ NMR spectroscopy. The formation of octa-1,5-diene [ $\delta 5.53(b r, 4 \mathrm{H}), 2.33(b r$, $8 \mathrm{H})$ ] was observed in $75 \%$ spectroscopic yield relative to the initial amount of 9 . Resonances attributable to free butadiene were also observed. No resonances attributable to $\mathrm{Cp}$ containing Mo products were observed.

\section{Thermal treatment of complex 3 in $\mathrm{CD}_{3} \mathrm{CN}$}

Complex 3 (15 mg) was placed in an NMR tube with $0.5 \mathrm{~mL}$ of $\mathrm{CD}_{3} \mathrm{CN}$. The tube was flame-sealed and heated to $100^{\circ} \mathrm{C}$ in an oil bath for $1 \mathrm{~h} . \mathrm{A}^{1} \mathrm{H}$ NMR spectrum showed the formation of hexa-1,5-diene $\left(\mathrm{CH}_{2}=\mathrm{CH}-\mathrm{CH}_{2} \mathrm{CH}_{2}-\mathrm{CH}=\mathrm{CH}_{2}\right.$ resonance at $\delta$ 2.14) and propene $\left(\mathrm{CH}_{2}=\mathrm{CH}-\mathrm{CH}_{3}\right.$ resonance at $\delta 1.70$, doublet with $J=6.1 \mathrm{~Hz}$ ) in a ca. 2:1 ratio, plus small amounts $(<20 \%)$ of other unidentified species, the major component of which shows a $\mathrm{CH}_{3}$ resonance at $\delta 1.46(d, J=5.1 \mathrm{~Hz})$.

Acknowledgements - We are grateful to the National Science Foundation (CHE-9508521) for support of this work.

\section{REFERENCES}

1. For Part 3, see ref. 4.

2. Wang, L.-S., Fettinger, J. C. and Poli, R., J. Am. Chem. Soc., 1997, 119, 4453-4464.

3. Poli, R. and Wang, L.-S., J. Am. Chem. Soc., 1988, 120, 2831-2842.

4. Wang, L.-S., Fettinger, J. C., Poli, R. and Meunier-Prest, R., Organometallics, in press.

5. Davidson, J. L., Davidson, K. and Lindsell, W. E., J. Chem. Soc., Chem. Commun., 1983, 452453.

6. Jolly, P. W., Krüger, C., Romão, C. C. and Romão, M. J., Organometallics, 1984, 3, 936-937.

7. Andell, O., Goddard, R., Holle, S., Jolly, P. W., Krüger, C. and Tsay, Y. H., Polyhedron, 1989, 8, 203-209.

8. Jolly, P. W., Acc. Chem. Res., 1996, 29, 544-551.

9. Astruc, D., Angew. Chem, Int. Ed. Engl., 1988, 27, 643-660.

10. Trogler, W. C. (Ed), Organometallic radical processes, Elsevier, Amsterdam, 1990.

11. Gordon, J. C. and Poli, R., in Synthetic Methods of Organometallic and Inorganic Chemistry, 
(Herrmann/Brauer), W. A. Herrmann, ed., Vol 8 , Georg Thieme Verlag, Stuttgart, 1997, p. 97-98.

12. Dilworth, J. R. and Richards, R. L., Inorg. Synth., 1990, 28, 33-37.

13. Faller, J. W., Chen, C.-C., Mattina, M. J. and Jakubowski, A., J. Organomet. Chem., 1973, 52, 361-386.

14. Faller, J. W., Johnson, B. V. and Dryja, T. P., J. Organomet. Chem., 1974, 65, 395-400.

15. Gibson, D. H., Hsu, W.-L., Steinmetz, A. L. and Johnson, B. V., J. Organomet. Chem., 1981, 208, 89-102.

16. Filippou, A. C. and Grünleitner, W., J. Organomet. Chem., 1989, 378, 387-399.

17. Wilke, G., J. Organomet. Chem., 1980, 200, 349 364.

18. Baker, R., Chem. Rev., 1973, 73, 487-530.

19. Tsuji, J., Adv. Organomet. Chem., 1979, 17, 141193.

20. Green, M. L. H. and Knight, J., J. Chem. Soc., Dalton Trans., 1974, 311-319.

21. Blau, R. J. and Siriwardane, U., Organometallics, 1991, 10, $1627<$ last-page $>1630$.

22. Borgmann, C., Limberg, C. and Driess, A., $J$. Organometal. Chem., 1997, 541, 367-375.
23. Betz, P., Döhring, A., Emrich, R., Goddard, R., Jolly, P. W., Krüger, C., Romão, C. C., Schönfelder, K. U. and Tsay, Y.-H., Polyhedron, 1993, 12, 2651-2662.

24. Weast, R. C., CRC Handbook of Chemistry and Physics, CRC Press, Cleveland, Ohio, 1976.

25. Stärker, K. and Curtis, M. D., Inorg. Chem., 1985, 24, 3006-3010.

26. Owens, B. E. and Poli, R., Inorg. Chim. Acta, 1991, 179, 229-237.

27. Feng, Q., Ferrer, M., Green, M. L. H., Mountford, P. and Mtetwa, V. S. B., J. Chem. Soc., Dalton Trans., 1992, 1205-1215.

28. Abugideiri, F., Gordon, J. C., Poli, R., OwensWaltermire, B. E. and Rheingold, A. L., Organometallics, 1993, 12, 1575-1582.

29. Blackburn, H., Kraatz, H.-B., Poli, R. and Torralba, R. C., Polyhedron, 1995, 14, 2225-2230.

30. Faller, J. W. and Ma, Y., Organometallics, 1986, 5, 1949-1952.

31. Pouchert, C. J. and Behnke, J., The Aldrich Library of ${ }^{13} \mathrm{C}$ and ${ }^{1} \mathrm{H}$ FT NMR Spectra, 1993. 